\title{
Regular o Estado
}

\section{Marcel Bursztyn}

\section{1 - Introdução}

O mundo do último pós-Segunda Guerra Mundial pode ser dividido em três grupos de países: os que adotaram sistemas de planificaçăo dirigidos por partidos comunistas, os que se inspiraram em Keynes para organizar uma intensa açăo planejada do Estado e os que tentaram mas năo conseguiram planejar. Estas últimas décadas têm testemunhado, portanto, um intervencionismo estatal generalizado, que parecia ter sepultado o velho ideal de "laissez-faire" preconizado por Quesnay em plena Revoluçăo Industrial.

Mas a última década, a dos anos 1980, mostrou que a fase estatizante chegava a um ponto crítico. Máquinas estatais emperradas, excesso de funcionários, má qualidade e pouca eficiência nos serviços públicos e déficits fiscais, sempre associados a crescentes cargas tributárias, estes săo alguns dos fantasmas responsabilizados pelo mau andamento das economias. A determinaçăo de exorcisá-los, em vários países desenvolvidos, exigiu um esforço de memória e alguma criatividade: princípios clássicos do liberalismo foram revividos e atualizados.

O agigantamento e a obsolescência dos aparelhos de Estado haviam atingido um tal ponto que no seio da sociedade começava a se

") Professor do Departamento de Economia e Finanças, Universidade Federal da Paralba - Campus II, Campina Grande, realizando Doutorado om Paris. 
ter a sensaçăo de que uma inversão cruel ocorrera: não era mais o Estado que estava servindo à Sociedade, mas o contrário.

A questăo pública pode empregar, hoje, de 15 a $25 \%$ da populaçáo ativa e absorver de 30 a $50 \%$ da renda nacional nos países mais avançados. Com tal ordem de grandeza, o Estado não pode ser visto como algo isolado, como um todo em si mesmo, mas sim a partir de suas relaçóes com a sociedade. Assim,

"o problema não é que o Estado seja eficaz em si, mas que as relações entre o Estado e a sociedade sejam tais que esta obtenha os serviços necessários e seja verdadeiramente ajudada por uma boa gestão pública." (CROZIER: 1987, p.69).

A evidência de que o Estado - e, particularmente, o estatismo - estava em crise atingiu seu paroxismo com o desmoronamento dos regimes socialistas da Europa do Leste, justamente no final da década da desestatização do Primeiro Mundo.

\section{II - Crise do Estado e receita liberal}

Quais as razoes da crise do Estado? Elas podem ser resumidas numa fórmula simples: quanto maiores as necessidades e as demandas de intervenção, maiores as dificuldades de se intervir; quanto mais complexo o sistema de relaçóes que gera o tecido social, maior o grau de mediaçăo do Estado de que ele necessita. Daí, surge um paradoxo: quanto maior a liberdade dos participantes no jogo social, mais necessária se torna a organização. Nesse sentido, os autores neo-liberais, que pregam o encolhimento geral do Estado, parecem incapazes de perceber uma regra fundamental: "é preciso muita organização para assegurar mais liberdade a um grupo crescente de pessoas." (ibid., p.71).

Mas, se as proposiçōes restritivas, veiculadas pelo pensamento neo-liberal, pecam por partirem de simplificaçōes analíticas reducionistas e por preconceitos filosóficos, elas náo devem ser, por outro lado, simplesmente desconsideradas. $\mathrm{Na}$ verdade, alguns pontos-chave são tangenciados por autores vinculados àquela corrente, notadamente no que diz respeito ao fato de que a modernização do Estado, um dos pilares do desenvolvimento, exige um abandono de hábitos e de princípios 
estatizantes tradicionais. Ou seja, mesmo recusando-se a essência da ética desestatizante, é imperativo que năo se caia no extremo do dogmatismo da lógica estatizante. Assim, um outro paradoxo é apontado por Crozier:

"é por que o sistema administrativo tornou-se tão importante, e por que sua eficácia condiciona o desenvolvimento de toda a sociedade, que ele deve mudar completamente de práticas e de filosofia. É possivel tolerar num Estado arcaico limitado certas disfunçóes e rotinas; mas elas se tornam insuportáveis num Estado moderno." (ibid., p.73).

Até mesmo a Suiça padece de problemas na gestão pública. Contando-se os empregados dos Estados cantonais e das cidades, aquele país possui, proporcionalmente à populaçăo, tantos funcionários quanto a França. Em ambos os países, o Estado assegura serviços com um grau de abrangência e de qualidade apreciável, sendo o primeiro, seguramente, superior. $E$ isso, que contribui para que a população esteja satisfeita e disposta a colaborar, é devido, em grande medida, ao fato do setor público daquele pais contar com uma estrutura institucional leve.

"Estado Modesto tem cada vez mais possibilidade de sobrepujar o Estado megalômano, pois seus cidadãos sentem-se inclinados a ajudá-to e năo paralisá-lo." (ibid., p.79).

A questão da centralizaçăo encontra-se extremamente associada à problemática da modernizaçăo do Esłado. A era Keynesiana e, mais particularmente, a fase do planejamento póssegunda guerra, constituiu um campo fértil para o crescimento centralizado das açóes do setor público. Assim, o autor citado apontava, já em 1964, e reafirma hoje, mais de duas décadas depois, que os problemas de conjunto do sistema, com seus aspectos interdependentes e profundamente coerentes, mas aparentemente contraditórios, são: (ibid., p.99 - citando seu livro "O Fenômeno Burocrático", Le Seuil, Paris, 1964).

- a predominância absoluta de regras impessoais sobre as necessidades e limitaçőes das situaçōes particulares;

- a centralização das decisóes, que devem ser tomadas num nivel que esteja fora das pressóes, mas de onde a visão e o conhecimento da realidade são insatisfatórios; 
- a estratificação dos quadros isentos a qualquer autoridade hierárquica, mas submetida à forte pressão de seus pares, perfeitamente iguais no interior de cada estrato e, assim, capazes de se opor aos superiores e aos clientes;

- enfim; a força sempre combatida mas sempre revivida, por ser funcionalmente indispensável, de um universo informal de poderes paralelos, através dos quais săo efetuados os ajustamentos necessários.

A lista acima resulta de um esquema analítico do caso francês. Para que se cosidere o caso brasileiro, é necessário, evidentemente, uma devida adaptaçăo, que evidencia um grau ainda maior de intensidade do problema.

Em primeiro lugar, a questấo da impessoalidade das regras, que na França constitui-se em problema por causa da pouca margem de manobra que deixa em termos de adaptabilidade a contextos específicos, apresenta-se, em nosso caso, como uma limitação ainda maior: năo só as normas são impessoais, como também săo extremamente mutantes, dada a própria rotatividade das esferas deliberativas da hierarquia, sua cultura de transformaçóes formais e seus sofriveis canais de comunicaçắo com as esferas executivas.

Em segundo lugar, o comportamento patrimonialista das elites politicas brasileiras, desvio secular que molda nosso sistema administrativo, impede que, mesmo num contexto de grande centralizaçăo e concentraçăo institucional, possa ocorrer o fenômeno da inexistência (ou fraca importância) de pressóes politicas. Na verdade, o quadro brasileiro apresenta um aparente paradoxo, já que mesmo as elites representativas de regióes econômica e socialmente atrasadas dispóem de um considerável espaço no poder centralizado, que carece de bases de apoio político regional e não pode prescindir dos caciques locais. Assim sendo, a centralizaçăo, que teoricamente significaria uma situaçăo em que a importância relativa de elites regionais menos importantes no contexto nacional tenderia a ser minimizada, assume no Brasil uma forma tal, que o quadro institucional é fortemente marcado pelo jogo de alianças políticas que caracteriza cada governo. $E$ isso acarreta, inevitavelmente, graves efeitos negativos na administraçăo pública, em termos de rotatividade, descontinuidade e năo profissionalismo dos quadros dirigentes (ver BURSZTYN; 1990, cap. VI). 
Em terceiro lugar, a questão da estratificaçăo do pessoal isento de autoridade hierárquica mas sujeito ao controle dos seus pares năo se constitui em fenômeno comum no Brasil. Um exemplo, talvez o único que caberia nessa categoria, é o da comunidade cientifico-tecnológica. Mas mesmo aí, existe um nítido sistema hierárquico que determina todo o processo decisório, e que se traduz através de um complexo jogo de relaçסes sociais, onde pesam aspectos subjetivos tais como regionalismo, patronato intelectual e rivalidades/afinidades acadêmicas.

Finalmente, a questăo dos poderes paralelos, esta sim, constitui-se em elemento chave para a interpretaçáo do modus operandi do serviço público brasileiro. Tendo em vista a fragilidade institucional, resultante do distanciamento entre o processo decisório e a realidade objeto da açăo do setor público, a prática tem revelado que o funcionamento efelivo dos serviços do Estado, com todas as falhas e limitaçరes, se deve exclusivamente à continuidade assegurada pelo corpo funcional constante. Ou seja, as instituiçбes vêm funcionando, ainda que precariamente, apesar de seus dirigentes e graças a seus funcionários. Essa excrescência, que constitui-se em paradigma do serviço público brasileiro, deve se constituir em chave para o enfrentamento do problema estatal brasileiro. E, nesse sentido, qualquer soluçăo que se apresente năo levando em conta o papel do funcionário enquanto elo da continuidade dos serviços públicos, tenderá a constituip-se em agravante do problema.

\section{III - A questão da desregulamentaço da economia}

Peça essencial do receituário neo-liberal, a desregulamentaçăo vem sendo apresentada pelos economistas $\theta$ gestores públicos favoráveis ao encolhimento do Estado como condição necessária $e$, muitas vezes, suficiente para a cura dos males do setor público e dos problemas que este estaria acarretando à economia como um todo. Mas a pressa em importar soluçбes tem acarretado efeitos colaterais: por falha de traduçăo ou por dificuldades de entendimento, o conceito de desregulamentaçăo năo raro é confundido com o de desregulaçăo, e isso tende a transformar a possivel soluçăo em complicador do problema. 
Pela cartilha liberal, as funçס̄es do Estado poderiam (e deveriam) ser reduzidas a um minimo desempenho fisiológico das atividades de defesa, justiça e policia, essenciais à garantia da soberania de cada naçá. Nesse sentido, todas as demais atividades poderiam (e deveriam) ser regidas pelos mecanismos de regulaçăo automática, leia-se: o mercado. Entretanto, visto dentro de um quadro real, esse ideal apresenta-se como uma abstraçăo, dificilmente aplicável em sua forma pura. Na prática, outros fatores, que transcendem o automatismo regulador do mercado, interagem e constituem-se em reguladores (ou desreguladores) tăo ou mais importantes, em certas circunstâncias. Conforme assinala Crozier:

"No vocabulário das ciências sociais, o termo regulaçăo se impôs para designar a açăo dos mecanismos corretivos que mantêm um sistema em existência. Diferentemente dos sisiemas físicos, que só podem comportar regulaçőes automáticas, os sistemas sấo mais abertos (...): a presença, em seu seio, de fenômenos de poder e de consciência os torna mais vulneráveis mas, ao mesmo tempo, mais capazes de adaptação." (ibid., p.123).

Fica, portanto, evidente que outros fatores devem ser também considerados, quando se busca a lógica da regulaçăo da economia. $E$, é preciso que se diga, muitas vezes essa lógica foge ao rationale da ciência econômica. O Brasil é rico em exemplos de açóes "reguladoras" que obedecem a decisర̃es estratégicas que, pelas forças do mercado, dificilmente teriam ocorrido no momento em que ocorreram. A criaçăo da siderurgia nacional, em Volta Redonda, nos anos de 1940, ilustra o caso. Mas o desenvolvimento da Prússia e do Japão da Restauraçăo Meiji, no século XIX, também atestam esse argumento.

\section{IV - Sobre a oposiçăo Mercado versus Estado}

O argumento de que a "lógica do mercado" materializa o ideal liberal clássico da "máo invisível" chega, uma década depois, aos paises menos desenvolvidos. Mas chega enfraquecido em sua lógica. Afinal, de que modo seria possivel aplicá-lo, em contextos em que o mercado, ainda em formação, encontra-se desorganizado, como é o 
caso nas regibes mais atrasadas, onde sobrevivem velhas formas de produçăo?

Aliás, essa questáo năo é original: nos anos 1860-1880 a América Latina, em plena fase de formação de seus sistemas econômicos nacionais, já enfrentava os dilemas "clássicos" da suposta antinomia mercado-Estado. Segundo ARNAUD (1983), tanto naquela época como hoje,

"tudo é definido, percebido, situado em termos de lógica das forças de mercado e de açăo do Estado e mercado, uma oposição que invade toda análise sobre as perspectivas atuais e justifica as restruturaçбes econômicas ou as modificaçóes políticas." (p. 21).

No espaço de um século, os sistemas econômicos nacionais se consolidaram, mas a velha ordem colonial, hierarquizada $\theta$ desigual, subsistiu ao nivel das relaçóes de intercâmbio entre países. Nesse sentido, outra questăo se apresenta, enfatizando a importância de um enfoque solidário dos conceitos de Estado $\theta$ mercado: como enfrentar o problema da regulaçăo em um sistema de mercado internacionalizado (como no caso das matérias-primas), onde o engajamento de um pais subdesenvolvido está longe de se constituir um exemplo de "concorrência perfeita"?

Analisando o problema do ângulo das economias latinoamericanas, portanto, a oposiçăo Estado-mercado constitui um falso dilema. Como dois pólos de um ima, săo elementos que se repelem, mas fazem parte de um mesmo elemento e săo, malgré tout, complementares.

O debate não deveria, tampouco, se estabelecer em torno da pertinência ou não de mecanismos e açסes de regulamentaçăo. Afinal, seria dificil negar a importância de um mínimo de regulamentação, capaz de assegurar o cumprimento dos contratos e a confiança necessária à realizaçăo dos negócios. O que importa, de fato, é estabelecer o que e como regulamentar e quem deterá o poder normativo e o de fazer vigorar as normas. $O$ estabelecimento de normas e princípios legais, a formaçăo de urn quadro técnico competente'e a definiçăo de limites claros, capazes de evitar abusos e omissóes, são imperativos. Mas tudo isso torna-se letra morta diante da persistência de uma cultura política imediatista $\theta$ patrimonialista, que impede a manifestaçăo dos princípios mais básicos e elementares tanto da "lógica do mercado" como da açăo 
estatal: solidez institucional, regras do jogo bem definidas, continuidade e lisura.

\section{V - Confusão conceitual: desregulaçăo não é desregulamentação}

Talvez por influência anglo-saxônica, o termo desregulaçăo vem adquirindo um uso que extrapola a abrangência do conceito. Considerando a definiçăo apresentada por HURL em análise das privatizaçōes. na Gră-Bretanha,

"desregulaçăo, sinônimo de liberalizaçăo, é a remoçáo de barreiras legais à entrada em um mercado previamente protegido, de forma a permitir às empresas privadas de competirem." (1988, p.3)

Tal definiçăo, na verdade, reduz a análise à intervençăo ou náo do Estado, fato que simplifica a questão a um extremo tal, que pouco ajuda o debate do tema: Na prática, contudo, os britânicos efetuaram desregulamentaçōes sem que tivesse havido desregulação. É o caso da privatizaçăo do sistema de transportes urbanos: é certo que a passagem à iniciativa privada representou uma valorizaçăo da variável mercado nas decisões económicas relativas a este setor, mas o Estado mesmo se encarrega de assegurar que o funcionamento do sistema obedeça a certos princípios inerentes ao bom atendimento a comunidade, constituindo um conjunto de regulamentaçסes paupável. O que ocorreu, de fato, foi uma mudança nos instrumentos regulamentares, que permitiu a privatizaçáo das empresas públicas. O uso do termo desregulamentação, aliás, nem é muito apropriado. Na verdade, o que vem ocorrendo na maioria das experiências de desestatização é uma reforma do sistema de regulamentaçōes, mas não uma extinção total de regulamentos. $O$ exemplo da privatizaçăo da estatal britânica das telecomunicaçరes, em 1984, é elucidativo: a eficiência do processo passou a ser monitorada por um órgăo especialmente criado para essa finalidade; e, dentre as limitaçбes estabelecidas, incluia-se a regulamentação de que as tarifas da British Telecom só poderiam ser majoradas por indices inferiores em $3 \%$ à inflação anual.

Ainda tomando-se o caso da Gră-Bretanha, é relevante assinalar que na prática, o Estado, mesmo valendo-se de uma 
política privatizante, não reduz a regulaçăo à simples abstraçăo de uma "lógica de mercado". Assim, como salvaguarda à perda do controle público sobre setores estratégicos da economia, e diante da determinaçăo de permitir mesmo a desnacionalizaçăo de empresas desses setores, foi criado um instrumento que garantia um poder acionário decisivo ao Estado, quando conveniente: a "golden share" ou "special rights share". Segundo aquele artifício, o Estado pode, sempre que julgar indispensável, assegurar uma salvaguarda contra qualquer eventual concentração de poder decisório nas empresas desestatizadas, através da preservaçăo de uma quota de participaçăo substantiva. Conservando em seu poder uma "golden share", a Coroa britânica mantém, até quando juigar necessário, um poder de veto que serve de garantia de que nenhum outro acionário pode assumir o controle da empresa em questăo. Segundo assinala SANTINI (1986), para as principais sociedades privatizadas, a natureza dos direitos reservados diz respeito aos seguintes elementos:

- a composição das instâncias dirigentes, sobretudo a nacionalidade dos administradores e do diretor geral;

- o controle da sociedade, limitando a maior participação a $50 \%, 15 \%$ ou $10 \%$, segundo o caso (no caso da British Telecom a quola fixada foi de $10 \%$ );

- a presenvação dos ativos da sociedade;

- a continuação da atividade da empresa;

- a participação do representante do departamento ministerial competente, enquanto portador da "golden share", nas reuniōes do conselho de administração.

Assim,

"se a capacidade de intervençăo do Estado nas sociedades desnacionalizadas foi sensivelmente reduzida, os poderes conservados pelas autoridades nessas empresas, entretanto, permaneceram, muitas vezes, importantes" (ibid., p.62).

A confusão conceitual entre desregulaçăo e desregulamentação tem sido uma prática comum nos dois principais conjuntos de atores diretamente envolvidos na questão. De um lado, encontram-se os teóricos neo-liberais, para quem o paradigma maior é o dom da "máo invisivel" exercido pelo mercado; do outro, 
situam-se certos tecnocratas, reificadores do poder regulador do Estado. No primeiro caso, a confusáo conceitual se deve ao fato de que o objetivo visado é, em última instância, o desmantelamento do Estado enquanto ente econômico; no segundo, trata-se de miopia comum a quem procura ver a realidade não como ela é, mas sim como se desejaria que ela fosse. O resultado inevitável dessa polarização é um diálogo de surdos que não ajuda, em nada, a possivel cooperaçăo entre os dois grupos, no sentido de se buscar soluçōes concertadas e acertadas. E é esse quadro de confusão e voluntarismo que vem inspirando $e$ orientando as açסes desestatizantes.

\section{VI - A era da desestatizạ̧ão}

Os anos 1980 foram, por excelência, a década da privatização de empresas públicas, no mundo desenvolvido. Boa parte do acervo produtivo acumulado nas măos do Estado, sobretudo após a Segunda Guerra Mundial, foi repassado ao setor privado. Não foi apenas a desregulamentaçáo, tal como ocorrido por exemplo nos EUA e na Grá-Bretanha (é o caso da liberalização dos hospitais Británicos para que contratem serviços de lavanderia privados, dando um fim ao monopólio estatal da roupa suja, em um caso típico de "franchising"), que deu a tônica ao processo. Houve, de fato, uma sensivel redução na açăo produtiva direta do Estado. Assim, para citar alguns exemplos, a França privatizou empresas do setor bancário e de seguros, o Japăo privatizou as telecomunicaçōes e o sistema ferroviário e a Grá-Bretanha vendeu à iniciativa privada indústrias automobilísticas e de petróleo. E é possivel mesmo afirmar que tal processo resultou em melhoria na eficácia dessas empresas: as tarifas baixaram no Japăo, os lucros aumentaram na Gră-Bretanha e a competitividade aumentou, em geral.

Na América Latina, por outro lado, aquela década correspondeu a um período de estagnação da açăo estatal, resultado do estrangulamento fiscal e da crise do endividamento. ${ }^{1}$

A década de 1990, a julgar pela tendência em curso, promete se constituir em década do desmantelamento do Estado. A

1) Segundo dados do Banco Mundial, a divida total latino-americana em 1989 era da ordem de 427,5 bilhoes de dólares, sendo que só o serviço correspondia, em média, a $40,5 \%$ desse valor. 
principal bandeira apresentada pelos novos governos, e com o apoio da comunidade financeira internacional (BIRD, FMI, Clube de Paris), é a da desestatização. Na Argentina, as primeiras cartas já foram jogadas em setores tais como aviaçáo, ferrovias e telecomunicaçб̌es. Ironicamente, nos três casos, destacaram-se como fortes candidatos e virtuais compradores empresas públicas espanholas que estăo passando ou já passaram por processos similares de desestatização. Iberia, Ferrocarriles e Telefónica, em plena fase de pragmatismo de mercado, se engajam em tamanha expansão além de suas fronteiras. Uma questão se apresenta, então: qual a coerência entre a estratégia de encolhimento nacional, resultante de uma rigorosa dieta de saneamento financeiro, $e$ a de expansăo internacional desses grupos? A resposta é, seguramente, o fato de tais investimentos representarem bons negócios. Afinal, a um Estado em bancarrota não sobra poder de barganha para obter preços compensadores. Nesse caso, o processo de desestatizaçăo corresponde também à desnacionalização.

O Brasil, tudo indica, segue a mesma estratégia adotada pelo governo argentino. Trata-se, segundo HURL (1988), de caso lípico de "venda das jóias de família para pagar os débitos". Nesse sentido, convém assinalar alguns pontos. Desfazer-se do patrimônio para cobrir uma dívida é sempre um expediente a ser considerado. Entretanto, há riscos e vícios que devem ser evitados. O primeiro deles, por se tratar de um caso específico de alienaçăo patrimonial - açáo efetuada por um delegado e não diretamente pela parte interessada - diz respeito à tendência a subestimar o valor real da venda, de maneira a acelerar o processo. Nesse caso, objetivos políticos de curto prazo podem ser atingidos, uma vez que há, sempre, uma entrada líquida de recursos para os cofres públicos ou um desengajamento do Estado em alguma atividade não rentável. Entretanto, analisando-se sob o ângulo econômico, a venda de um bem abaixo de seu valor real constitui-se em mau negócio. Tal tipo de problema tem sido comum nos paises que se lançaram na vanguarda das experiências privatizantes. O governo francês vendeu, à iniciativa privada, várias empresas que haviam passado ao poder público por conta de insolvência. O Estado investiu um volume considerável de recursos par sanear e tornar vendável essas sociedades, que são chamadas de "canard boiteux" ("patos mancos"). O processo de venda constituiu-se de episódios controvertidos pois, pouco tempo após, os novos detentores repassaram os negócios a terceiros, com grande margem de lucro, 
em nítida demonstraçăo de que o poder público havia permitido uma socializaçăo de prejuizos seguida de privatizaçăo de lucros.2

A experiência britânica é, também, rica em ilustraçōes do problema da sub-avaliaçăo dos valores reais (under-pricing) das empresas a serem desestatizadas. O resultado, que atesta a subestimaçăo, é sempre expresso por uma demanda maior do que a oferta de títulos das empresas em questáo. O caso da Rolls-Royce, cujas açסes foram oferecidas pelo poder público em 1987, merece referência: o preço estabelecido foi táo baixo, relativamente à propensão da populaçăo a subscrever açбes ("over-subscription"), que os pedidos de compra tiveram de ser racionados, na razăo de 15 'para 40 açбes solicitadas (cf. HURL, 1988, p.57). Nesse sentido, é possivel inferir que o Estado teria arrecadado bem mais se a avaliaçăo tivesse sido mais realista. Quem ganha com isso? Num primeiro momento, evidentemente, săo os compradores em geral, ou seja a população. Entretanto, a tendéncia é que haja, num segundo momento, uma certa reconcentraçăo, nas mạos de um grupo mais reduzido de detentores. Nesse processo, os compradores Iniciais efetuam grandes lucros por unidade, mas a idéia inicial de democratizaçăo da propriedade se reverte, na prática.

"De fato, quando da venda, muitos foram os compradores de títulos, mas poucos os conservaram, como demonstra o exemplo da British Aerospace. cujas açóes se concentram em poder de apenas 28.000 pessoas um ano após a desnacionalização, quando esse número era de 158.000." (SANTINI, 1986, p.59).

A prática tem mostrado, também, que à questão da má avaliaçáo da demanda potencial pelos títulos das empresas a serem desestatizadas ("under-pricing" x "over-subscription"), há que se agregar uma outra. Trata-se da açáo saneadora praticada pelo poder público, no sentido de tornar as referidas empresas atrativas à iniciativa privada. Esse processo, que invariavelmente implica custos para os cofres públicos, que năo necessariamente serăo ressarcidos, tende a evidenciar um paradoxo: a razăo das privatizaçסes é a ineficiência das empresas; ora, uma vez saneadas,

2) Os casos mais notáveis sáo os dos grupos Boussac, do setor têxtil, EmpainSchneider, papelelro, estaleiros Lexmar. Ver: Science \& Vie Economie, $n^{2}$ 61. majo/1990, "Comment s'enrichir avec les cadeaux de l'État". 
as mesmas tendem a tornar-se eficientes (do contrário, não haveria demanda... ) e, nesse sentido, a razăo de ser da privatização perde muito de sua força. Fica claro, portanto, que o binômio "setor público ineficiente - setor privado eficiente" năo constitui uma antinomia imutável a priori. A razáo de ser da desestatização deve ser entendida a partir de outros elementos, que transcendem a esfera da racionalidade microeconómica de cada empresa.

Também, no que diz respeito ao argumento macroeconômico da irrigaçăo das finanças públicas resultante das desestatizaçóes, algumas consideraçóes săo pertinentes. No caso da França, um estudo publicado em 1987 dava conta que a contribuiçáo das privatizaçóes para o desendividamento do Estado foi bastante modesta: das receitas obtidas, a rubrica "reduçăo do déficit público" foi contemplada com recursos da ordem de 34 bilhoes de francos em 1987 e previsăo de 35 bilhóes para o ano seguinte, quando aquele déficit situava-se nos patamares de 129 e 115 bilhóes de francos, respectivamente. Nesses termos, o máximo que se consegulu fol uma desaceleração do aumento da dívida, mas năo uma reduçáo (cf. França; 1987, p.16).

No caso da Gră-Bretanha, a receita pública obtida ao longo de uma década de privatizaçăo (de 1979 a 1988), incluindo-se as vendas de participaçסes do Estado em empresas comerciais $\theta$ de empresas públicas, foi de aproximadamente 25 bilhőes de libras, 0 que corresponde a $7,5 \%$ do PIB daquele país em 1987 (OCDE; 1989 , p. 122 e 140). Tal cifra, que contribuiu bastanto para medidas de impacto politico do tipo de reduçåo da carga tributária ${ }^{3}$, náo resolveu, no entanto, o problema da divida pública: ao longo de toda a década das privatizaçðes, o único ano em que as despesas do setor público foram inferiores às receitas fol 1988, justamente quando a venda das empresas do Estado chegou a seu ápice (5 bilhoes de libras em um só anol). (ibid, p. 101 e 138).

3) Quanto a este aspecto, vale assinalar que o perfodo em questáo correspondeu ao de uma importante contribuição fiscal do petróleo extraldo do Mar do Norte: as receitas do Estado británico relativas ao setor petroielro que, em 1977, situavam-se no patamar de 0,2 bilhoes de libras, passam, em 1987, cifra de 4,8 bilhoes de libras; malor, portanto, do que a receita obtlda pelas privatizaçóes no mesmo ano (ct. SANTINi; 1988, p. 23 OCDE, 1990, p.101). 


\section{VII - Lições}

O balanço de uma década de experiências internacionais em desestatizaçáo das economias é elucidativo da real importáncia daquela estratégia, enquanto instrumento de superaçăo dos impasses diante dos quais se encontra o setor público. De uma maneira geral, os diferentes paises apresentavam um quadro de ineficiências, que se traduzia em déficil público e mau atendimento aos cidadáos. A década de 1980 fol, portanto, marcada por processos de limitaçóes das fronteiras de açăo do Estado, cujas implicaçб̌es săo de grande envergadura e náo podem ser avaliadas no curto prazo. Alguns dos efeitos mais imediatos foram analisados nas páginas precedentes. Mas será, sem dúvida, a longo prazo, que um julgamento judicioso poderá ser efetuado. Nesse sentido, a maior parte das obras analíticas disponiveis sobre cada caso ainda apresenta um caráter bem mais descritivo do que prospectivo.

Há, entretanto, algumas consideraçóes que devem ser assinaladas, desde já. A primeira delas é o fato de que a década da desestatização correspondeu, para os paises que empreenderam esse processo, ao período de recuperaçăo econômica que sucedeu à crise do segundo choque petrolifero do início dos anos $1980^{4}$. A baixa do preço do barril do petróleo, aliada ao bom desempenho geral da economia norte-americana (que se refletiu em aumento do comércio internacional), bem como a modernizaçăo tecnológica, permitiram um desempenho bem satisfatório das economias indusirializadas. Segundo dados da OCDE (1990) relativos ao quinquênio 19821987, o PIB do Japão cresceu a uma média de 3,9\% ao ano, o dos EUA $4,3 \%$, o da Gră-Bretanha $3,2 \%$, O da França 1,6\% e o da Alemanha Ocidental $2,1 \%$. Todos os 25 paises membros daquela organizaçăo apresentaram taxas médias de crescimento do PIB positivas e superiores ao aumento demográfico no período (salvo a lugoslávia, para a qual não se dispóe de dados).

O bom desempenho geral da economia não pode, entretanto, ser atribuido às medidas desestatizantes. Alguns dos paises em questão empreenderam processos ousados de privatizaçăo de empresas públicas, mas outros foram bem tímidos nesse processo; no entanto, todos apresentaram índices econômicos encorajadores. Nesse sentido, uma primeira lição a ser tirada é que, até o

4) Em novembro de 1980 o preço do barril de óleo bateu seu record historico, ao atingir a marca:dos 39,25 dólares. 
momento, fica difícil explicar o crescimento econômico como uma decorréncia direta da desestatizaçăo.

Os anos 1990, que começam com sintomas de desaceleraçăo das economias desenvolvidas, com uma monumental elevaçăo dos cusios energéticos (resultante da crise do Golto Pérsico) ${ }^{5}$ e com as máquinas estatais já bastante aliviadas de seu "excesso de peso", servirăo de laboratório para o teste do grau de relaçăo entre crescimento econômico e desestatizaçăo.

Outra consideração importante diz respeito ao "funcionário". Alvo preferencial do argumento neo-liberal, essa categoria social sofreu importantes revezes na década de 1980 . Náo se tratou, como havia sido anunciado, de processo de "távola rasa" no serviço público, com demissర̋es em massa. O que ocorreu, de fato, fol uma transferência de empregos públicos do Estado para a iniciativa privada, como corolário das privatizaçóes. Só na Gră-Bretanha, aproximadamente metade do milháo e meio de funcionários, recenseados no inicio da década, saiu da alçada pública. $E$ isso trouxe efeitos que văo da restrufuraçăo do quadro sindical até a reduçăo da folha de pagamento do Estado. Uma vez na iniciativa privada, os exfuncionários passam a ser regidos por mecanismos produtivistas diferentes do modus vivendi do serviço público tradicional. A adaptaçăo é dificil e, por vezes, traumática. E a lógica fordista, evidentemente, tende a buscar economias de măo-de-obra que se traduzem em elevaçăo das taxas nacionais de desemprego.

A maré anti-funcionário, fundamentada numa realidade onde - serviço público é, de fato, criticável em sua eficiência, representa, por outro lado, um grave risco de se negligenciar a importância do recurso humano. Năo é mantendo um corpo funcional pesado e improdutivo que o Eslado resolverá as crescentes demandas sociais por seus serviços. Mas também năo é descartandose indiscriminadamente, ou náo reciclando os quadros, que tais demandas serăo satisfatoriamente atendidas. Conforme assinala CROZIER (1987, p. 214), o funcionário "poderia e deveria ser a principal alavanca da modernizaçăo do Estado".

5) O jornal Le Monde de 19/9/90 assinala que a elevaçáo do prego do barril de petróleo, que em 17/9/90 atingira o patamar de 33 dólares, representou uma. das mais rápidas altas jamais verificadas: $120 \%$ em dois meses. Uma semana depois, o preço do bruto já atinga 40 dólares no mercado de Londres. 
A questão do risco de desperdicio do recurso humano é, na verdade, uma outra face do problema do descarte do património produtivo público em condições nem sempre satisfatórias. Nesse processo, tem pesado muito a determinância que o nivel politico vem exercendo sobre a racionalidade econômica. Interesses de curto prazo impóem-se sobre os de longo prazo e a conta recai invariavelmente sobre a sociedade. Tal tipo de problema, típico de paises subdesenvolvidos, não poupa as nações mais avançadas. $\mathrm{Na}$ Gră-Bretanha, a receita obtida pelas privatizaçōes constituiu-se em importante respaldo à determinação de reduzir a carga tributária. De fato, os impostos foram reduzidos e o periodo de mandato dos "tories" foi confortavelmente renovado. Mas o final dos anos 1980 coincidiu com uma necessária elevaçăo da arrecadaçăo, pois os recursos apurados com as privatizaçoes haviam servido ao financiamento do déficit público, mas não à reduçăo das despesas. Resultado: revolta popular contra o aumento dos impostos, no primeiro semestre de 1990 e taxa de inflaçăo próxima aos $11 \%$ anuais, no segundo semestre do mesmo ano, ultrapassando o índice que antecedeu a queda do gabinete trabalhista, em 1979.

Um outro ensinamento a ser tirạdo das experiências desestatizantes é o de que a "lógica do mercado" não deve ser reificada como o regulador por excelência das açōes econômicas. 0 livre jogo das forças de mercado é, sem dúvida, uma condiçăo necessária, mas não é suficiente para uma regulação econômica que atenda a objetivos outros que a maximização do lucro. Imperativos do desenvolvimento social, tais como equidade e preservaçăo do meio ambiente, dificilmente podem ser preseguidos sem um conjunto de normas que devem ser seguidas pela totalidade da sociedade. Assim, a regulamentação constitui-se em importante instrumento da regulação. O repúdio preconizado pelas teses neoliberais, nos anos 1980, a qualquer regulamentaçăo, se legitimou no arcaísmo dos regulamentos disponiveis. Mas a prática tem mostrado que a saída não é o ideal liberal, mas a modernização instrumental, que passa pela necessária simplificação e agilizaçăo das normas.

Para tanio, uma estratégia vem se firmando, nos últimos anos, nos paises mais avançados, de forma a resgatar o ideal regulador perdido nos descaminhos da prática do planejamento: a Avaliação de Políticas Públicas. A partir de propostas práticas inovadoras, sistemas de avaliaçăo começam a ser estruturados, abrindo espaço para uma monitoração das ações do Estado que 
transcende as esferas meramente contábeis ou técnicas. A questão da cidadania e da democracia voltam, nesse sentido, a orientar um debate que, se bem encaminhado e despojado de objetivos políticos imediatistas, poderá ajudar a "regular o Estado".

"A liberdade, a capacidade de agir, năo săo dadas nem se decretam por leis, por melhores que estas sejam; elas se conquistam, pouco a pouco, pela experiência, se as regulaçōes - que não podem deixar de limitálas - săo favoráveis. Cabe ao Estado fazê-las emergir e mantê-las; e ao politico cabe guiar o Estado. Tanto um como outro devem investir no conhecimento e nas ocasióes de aprendizagem". (ibid., p.312).

\section{VIII-Conclusão:Liberalismo e Apartheid Social}

Vista sob um ângulo politico, a desestatização e, mais particularmente, a privatizaçăo de empresas públicas, apresentase como um importante instrumento de legitimaçáo política, da mesma forma como o planejamento fora utilizado desde o último pós-guerra. A crise fiscal e o endividamento público inviabilizam qualquer projeto governamental de inspiraçăo social, nos países que, como o Brasil, conquistaram um espaço democrático formal a partir do desmoronamento de um regime político ditatorial. O descrédito da ação planejada do Esłado materializa, na verdade, a desilusăo da sociedade em relaçăo à anunciada via de superaçăo do subdesenvolvimento, táo desgastada por planos governamentais que prometiam " 50 anos em 5 ". Nesse sentido, a bandeira desestatizante constitui uma alternativa atraente para a esfera decisória, na medida em que acena com possiveis reduçóes nos gastos públicos e, dessa maneira, como elemento de soluçóes para a crise fiscal.

O risco, entretanto, de tal via é, segundo assinalaram SALAMA e VALIER (1990, p.201), que "a retirada do Estado de certas despesas conduz a uma ausência de Estado". E essa ausência tende a reforçar o desenvolvimento de estruturas paralelas de poder, que preenchem lacunas sobretudo em contextos onde certos setores da sociedade carecem de normas e hierarquias legítimas.

O crescimento contingente de pessoas virtualmente despojadas do status da cidadania, sua exclusão progressiva dos 
canais formais de interaçăo com a sociedade civil e a sistemática repressăo aos "marginais", transformam o Estado em corpo externo e estranho a seus olhos. Assim, à célebre definiçáo de Engels, de que - Estado 6 uma instância que se situa "por fora e por cima da sociedade civil", deve-se agregar um complemento, quando se considera a percepçáo dos menos favorecidos: ele se situa por fora, por cima e contra. É licito, portanto, supor que a restauraçăo do poder civil eleito, em 1990, significou uma decisiva legitimaçăo politica a nivel de governo no Brasil. Mas isso năo implica automaticamente a legitimidade do Estado.

Numa sociedade onde o llegal - jogo do bicho, mercado paralelo do dólar, trabalho clandestino - tornou-se norma, o reconhecimento de lideranças politicas náo implica necessariamente consciência, reconhecimento e sujeiçăo voluntária e consensual às instituiçóses da "civitas" ou "república". E isso trai qualquer prescrição teórica, de Hobbes a Habermas.

Para alguns setores da sociedade, na prática, o Estado adquire forma material apenas em sua forma policial. E, nesse sentido, năo parece seguir a fórmula clássica de Maquiavel, que propunha um ideal para o Príncipe: ser amado e temido ou, năo podendo ser os dois, ser ao menos temido. Nosso Leviathan deformado pode ser temido, mas é também desprezado e até odiado.

Onde o Estado sempre fol mediatizado por politicos clientelistas, reais elos de ligaçăo entre poder público e sociedade civil, a questão da legitimidade só se coloca em relaçăo a esfera politica. E onde a açáo pública sempre teve dominância assistencialista, a expectativa frente à instituiçőes se limita à obtenção de prebendas. É, portanto, irreal pensar em participaçáo ou defesa de um ente que é percebido como estando fora, acima $e$ contra uma parcela da sociedade.

A bandeira liberal dispōe, nesse sentido, de ampla margem de açăo nos países onde, ao contrário dos berços do "Welfare State", consolidou-se uma autêntica situaçăo de "apartheiă" social. 


\section{IX - Bibliografia Citada}

BURSZTYN, Marcel. O País das Alianças - elites e continuísmo no Brasil, Ed. Vozes, Petrópolis, 1990.

CROZIER, Michel. État Modeste, État Moderne. Ed. Fayard, Paris, 1987.

FRANÇA. "Les privatisations avant et aprés la crise boursière de l'automne 1987", Regards sur l'Actualité, Ed. La Documentation Française, Paris, dez/1987.

HURL, Brian. Privatization and the Public Sector. Ed. Heinemann Educational, Oxford, 1988.

Le Monde. Dossiers et Documents: "Les Fardeaux de la Dette", no 180 , Paris, set/1990.

OCDE. Études Economiques de I'OCDE - Royaume-UnI, OCDE, Paris, 1990.

SALAMA, Pierre e VALIER, Jacques. L'Économie Gangrenée. Ed. La Découverte, Paris, 1990.

SANTINI, Jean-Jacques. "Les Dénationalisations en GrandeBretagne", Cahiers Français, ํㅜ 228, Ed. La Documentation Française, Paris, 1986.

. "L'Economie Britanique: le choix liberal". Notes et Études Documentaires, $n^{-}$4853, Ed. La Documentation Française, Paris, 1988. 